\title{
The significance of monitoring high mountain environments to detect heavy precipitation hotspots: a case study in Gredos, Central Spain
}

\author{
Enrique Morán-Tejeda ${ }^{1}$ (D ) José Manuel Llorente-Pinto ${ }^{2} \cdot$ Antonio Ceballos-Barbancho $^{2} \cdot$ Miquel Tomás-Burguera $^{4}$. \\ César Azorín-Molina ${ }^{5}$. Esteban Alonso-González ${ }^{3}$. Jesús Revuelto ${ }^{3}$. Javier Herrero ${ }^{6}$. Juan Ignacio López-Moreno ${ }^{3}$
}

Received: 22 April 2021 / Accepted: 15 September 2021 / Published online: 28 September 2021

(c) The Author(s) 2021, corrected publication 2022

\begin{abstract}
In 2015, a new automatic weather station (AWS) was installed in a high elevation site in Gredos mountains (Central System, Spain). Since then, a surprisingly high number of heavy precipitation events have been recorded (55 days with precipitation over $50 \mathrm{~mm}$, and a maximum daily precipitation of $446.9 \mathrm{~mm}$ ), making this site a hotspot in Spain in terms of annual precipitation ( $2177 \mathrm{~mm}$ year) and extreme precipitation events. The neighboring stations available in the region with longer data series, including the closest ones, already informed of wet conditions in the area, but not comparable with such anomaly behavior detected in the new station (51\% higher). In this study, we present the temporal variability of detected heavy precipitation events in this mountain area, and its narrow relation with atmospheric patterns over the Iberian Peninsula. Results revealed that $65 \%$ of the events occurred during advections from West, Southwest, South and cyclonic situations. A regression analysis showed that the precipitation anomaly is mostly explained by the location windward to the Atlantic wet air masses and the elevation. However, the variance explained by the models is rather low (average $\mathrm{R}^{2}$ for all events $>50 \mathrm{~mm}$ is 0.21 ). The regression models underestimate on average a $60 \%$ intensity of rainfall events. Oppositely, the high-resolution weather forecast model AROME at $0.025^{\circ}$ was able to point out the extraordinary character of precipitation at this site, and the underestimation of observed precipitation in the AWS was about $26 \%$. This result strongly suggests the usefulness of weather models to improve the knowledge of climatic extremes over large areas, and to improve the design of currently available observational networks.
\end{abstract}

\section{Introduction}

Mountains are known as topographically complex territories where atmospheric conditions radically change with respect to plain terrain principally due to the effect of elevated

Enrique Morán-Tejeda

e.moran@uib.es

1 Department of Geography, University of the Balearic Islands, 07122 Palma, Spain

2 Department of Geography, University of Salamanca, 37002 Salamanca, Spain

3 Pyrenean Institute of Ecology, CSIC, 50059 Zaragoza, Spain

4 Centre National de Recherches Météorologiques, Université de Toulouse, Météo-France, CNRS, 31057 Toulouse, France

5 Desertification Research Center, CSIC, 46113 Moncada, Valencia, Spain

6 Andalusian Institute for Earth System Research, University of Cordoba, 14071 Cordoba, Spain topography and the associated energy gradients and vertical motion of air. Aside from the temperature lapse rate with elevation, one of the most prominent effects of mountains over atmospheric variables is the enhancement of precipitation amounts as compared to lowlands. Although the underlying process is complex and involves interaction of multiple atmospheric factors at different scales (from cloud microphysics to large-scale atmospheric circulation) (Colle et al. 2013), the general scheme involves the forced uplift of air masses by the topographical barrier, the consequent adiabatic cooling and condensation of water vapor that facilitates snow crystal growth to form eventual falling snow flakes or raindrops (Barry 2008). This type of convective precipitation, commonly known as "orographic precipitation" (Smith and Barstad 2004) usually involves larger values of precipitation in mountains compared with plain terrain. However, the relationship between precipitation and elevation is not linear and larger amounts of precipitation in high mountains are more likely to occur at midway up the slopes rather than in upper reaches, and high precipitation amounts can 
be recorded as well at the leeward side of the mountains (Frei and Schär 1998; Houze 2012; Ogrin and Kozamernik 2020). Heavy precipitation events associated to orographic uplift together with steep topography involve potential risks on the mountain slopes or in downstream areas where population often concentrates. Numerous damaging processes have been reported in mountain areas associated with heavy precipitation, including floods (Morán-Tejeda et al. 2019; Ruiz-Villanueva et al. 2013; Weingartner et al. 2003), landslides and rockfalls (Melillo et al. 2020; Stanley et al. 2020; Valenzuela et al. 2018), or snow avalanches (Abermann et al. 2019; Stimberis and Rubin 2011).

Despite the good theoretical knowledge about orographic precipitation, many of these intense precipitation events remain undetected, except when they cause material or human damages. This is due to the intrinsic stochastic nature and high spatial variability of precipitation, which becomes larger when dealing with extreme events. Moreover, the scarce number of meteorological observatories in mountain regions when compared to the dense network of observatories in the lowlands derives in a misrepresentation of mountain meteorology, potentially causing over- or underestimation of real precipitation volumes. This may have consequences not only on hampering sound scientific knowledge, but also for practical issues such as risk prevention, or water resources management among others (Lundquist et al. 2019). Solutions to overcome this issue include two sets of techniques with differing approaches, forecasting and real-time remote sensing observation. Forecasting intense precipitation requires downscaling techniques to adapt the coarse spatial resolution of the latest numerical weather prediction models to finer scales that enable reproducing mountainous complex terrain. These include dynamical downscaling using non-hydrostatic limited area models of spatial high resolution, such as AROME model (Bengtsson et al., 2017). This model, and some variants, is operationally used for National Weather Services in France and Spain among other countries. While the short-term forecasting power of weather models is not under discussion, their potential to accurately predict the location and amounts of convective precipitation events in complex terrain is still limited (Ferrari et al. 2020; Lorenzo-Lacruz et al. 2019; Moya-Álvarez et al. 2018; Sarmadi et al. 2019). On the other hand, remote sensing atmospheric products such as those provided by ground-based weather radars are increasingly used by meteorological agencies and researchers to improve forecasting and nowcasting, early warning, and as well for mapping and creating thunderstorms climatologies (del Moral et al. 2018; Ochoa-Rodriguez et al. 2019; Peter et al. 2015), and specifically for mountain areas (Germann et al. 2006). Weather radars allow identifying convective cores and tracking their life cycle (del Moral et al. 2020), and have been proved to accurately reproduce precipitation volumes (Quantitative
Precipitation Estimation, QPE) when compared with observations in precipitation gauges, although their accuracy decreases with range from the radar (Burcea et al. 2019). Their use in mountain terrain involves further limitations, including the beam blockage by topography affecting areal coverage of QPE if the radar is located at the bottom of a valley or at mountain-surrounded plateau (such as the case of Spain), the inability to detect the changes that precipitation may undergo (e.g. phase change) in the course between radar detection and arrival to the ground if the radar is placed at the top of the mountain, or the attenuation of the radar signal in heavy rain (Germann and Joss 2004; Khanal et al. 2019). An approach to overcome these limitations is the use of blended radar-rain gauge products, as recently shown for Switzerland by Barton et al. (2020).

Spain depicts a high spatio-temporal variability in precipitation amounts due to its location between the Atlantic and Mediterranean seas, their contrasted climatic influences and the seasonal-varying influence of the polar jet stream and the North Atlantic Oscillation (Capel-Molina 1995; Rodriguez-Puebla et al. 1998). Its complex topography, with several mountain chains running longitudinally from East to West, elevated plateaus and wide river valleys, increases the complexity in the distribution of precipitation. Various attempts to map the spatial distribution of precipitation in Spain or the Iberian Peninsula have been carried out to the date, with increasing accuracy over time. Capel-Molina (1995) pointed out that the "humid Spain", with annual precipitation amounts over $800 \mathrm{~mm}$, encompasses the northwest Atlantic sector (Galicia, Asturias), as well as the large mountain systems including the Pyrenees, the Cantabrian mountains or the Central System. Ninyerola et al. (2007), mapped annual amounts of precipitation ranging from scarce $200-400 \mathrm{~mm}$ in the southeast of the Iberian Peninsula and in the lowest sectors of the large basins of the Ebro, Duero, Tajo and Guadiana rivers, to $1400-1600 \mathrm{~mm}$ in the northwest and north fringes open to the Atlantic ocean, and in the western sector of the Pyrenees. Besides the Pyrenees, only very few spots of high precipitation are detected in mountains by Ninyerola et al. (2007), including small locations in the Central System, and Sierra de Grazalema (south of Spain), but with precipitation values which differ greatly from small scale studies, which show amounts over $2000 \mathrm{~mm}$ per year (García et al. 2017; Naranjo-Barea et al. 2017). This exemplifies the large uncertainty when mapping precipitation amounts if mountain areas are misrepresented; uncertainty that must be larger when dealing with daily values and extreme events of precipitation. Serrano-Notivoli et al. (2017) acknowledged that only $2 \%$ of the precipitation stations are located above $1500 \mathrm{~m}$.asl. in Spain, whereas $4 \%$ of the Spanish territory exceeds such elevation. These authors showed, in their daily gridded precipitation dataset, a much better representation of mountains, and the highest 
values for daily amounts of precipitation are observed, along with areas in the Mediterranean coast, in the Pyrenees, in the Central System and in the Grazalema mountains. The Central System does appear, therefore, between the hotspots of precipitation in Spain. Because its location and geographical alignment (Fig. 1) this mountain range constitutes the first orographic barrier that west advections associated to deep depression systems in the Atlantic encounter as they enter the Iberian Peninsula. These wet air masses, frequently in the form of atmospheric rivers (Ramos et al. 2015) are forced to uplift inducing orographic convection, or seeder-feeder precipitation enhancement (Browning and Hill 1981), and therefore intense precipitation compared to surrounding areas (Durán et al. 2013). García et al. (2017) showed wide areas within the $2000 \mathrm{~mm}$ year ${ }^{-1}$ isohyet, and pointed out to frequent events of more than $100 \mathrm{~mm}_{\text {day }}{ }^{-1}$ in the Gredos massif (located at the heart of the Central System) by using stations of the Spanish State Meteorological Agency (AEMET) network. However, still this data is subject to large uncertainty and rain gauges of AEMET network located in mountain environments are likely underestimating real precipitation volumes due to: (i) rainfall that can be extremely variable in space and time in areas of complex terrain; (ii) tipping bucket rain gauges might not be correctly recording high intensities (Molini et al. 2005); (iii) snow precipitation is underestimated or not properly recorded in unheated rain gauges (Nitu et al. 2019; Rasmussen et al. 2012); and (iv) unshielded rain gauges in windy mountain sites introduce large biases in precipitation measurements (Smith et al. 2020).

In 2015, an automatic weather station (AWS) was installed close to the fringe of the Gredos massif (sub-massif of the Central System) at 1947 m.asl (Fig. 1c). It was equipped with a Geonor rain gauge, replaced by an OTT Pluvio2 in 2017, both equipped with single Alter wind shields and adapted to all types of precipitation (see more details in methodology section). This precipitation gauge soon revealed surprisingly high pluviometric values at both, annual and event scales. After 5 years of continuous weather monitoring, here we present data on the temporal evolution of precipitation, focusing on extreme or high intensity events. Specifically, the objectives of this study are: (i) to

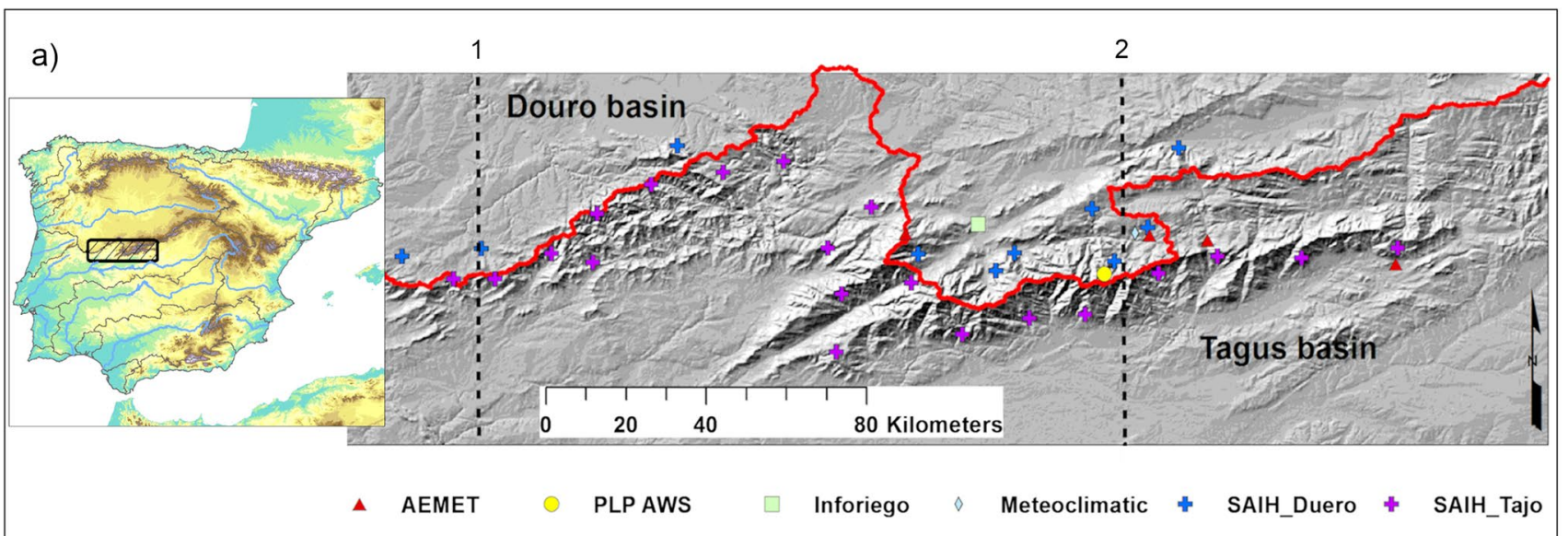

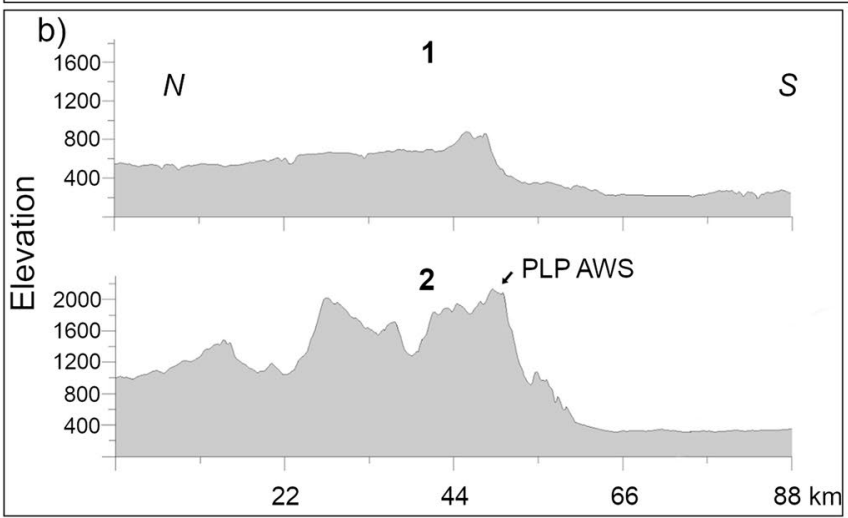

Fig. 1 Study area. a Iberian Peninsula, the Central System mountains and meteorological stations used for this study. Red line represents the divide between the Douro and Tagus basins and dashed lines indicate the direction of the topographic profiles of $\mathbf{b}$. b Topographic

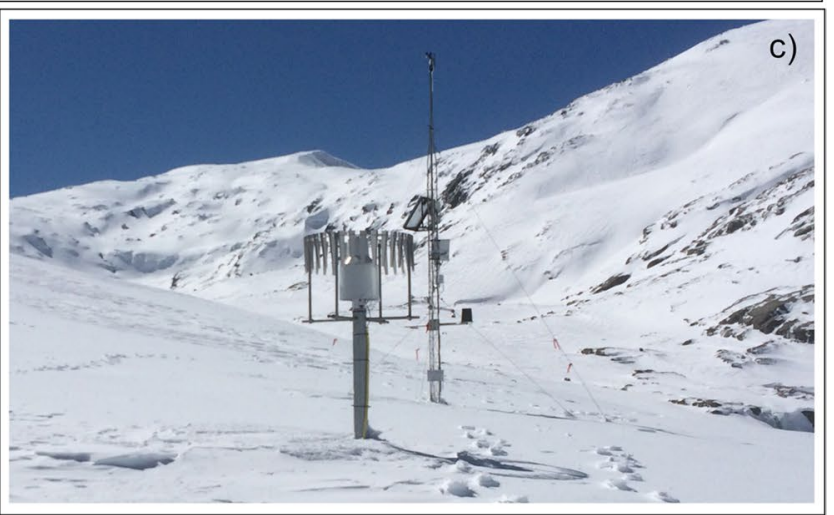

profiles from North to South of the mountain system. Profile 2 corresponds to the Gredos massif. c Photograph of the PLP AWS in March 2018, with the OTT PLuvio2 rain gauge in the forefront 
characterize the temporal variability of heavy precipitation events and the associated weather patterns triggering these events in the Gredos massif, (ii) to quantify the spatial extent of this precipitation hotspot and assess to which degree it is predictable from topographic and geographic variables, and (iii) to assess the capability of a high resolution weather model to predict the most heavy precipitation events in this mountain site.

\section{Study area}

The study area comprises the eastern sector of the Central System, a mountain system in the Iberian Peninsula that acts as drainage divide between the Tagus (south) and Douro (north) river basins (Fig. 1a). This topographical barrier includes a series of mountain ranges of diverse elevation, aspect and thickness, with Gredos range showing the highest elevation (> 2500 m.asl.) and most jagged terrain. Such diversity in the relief can be seen in the topographic profiles of Fig. 1b. The Central System also separates the north and south Spanish plateaus, with an average difference of elevation of about $400 \mathrm{~m}$. This makes the slope of the southern façade much steeper, which explains the more complex bioclimatic features, as well as the highest intensity of storms, occurring when Atlantic wet air masses enter the Iberian Peninsula from the southwest.

Climate shows typical Mediterranean features, although the elevation gradient and the contrasted aspect between façades induce large climatic diversity. Precipitation ranges from $500 \mathrm{~mm}_{\text {year }}{ }^{-1}$ in the lowest terrain and the leeward side of the mountain system, to more than $2000 \mathrm{~mm}_{\text {year }}{ }^{-1}$ in the windward and more elevated terrain. Winter snowpack is frequently present in the summits. Average annual temperature ranges between $6{ }^{\circ} \mathrm{C}$ at the top of the mountains and $14{ }^{\circ} \mathrm{C}$ in the lowlands (Ninyerola et al. 2005). Vegetation shows a clear altitudinal zonation, with natural forests of Quercus rotundifolia and Quercus pyrenaica, followed by a Pinus sylvestris belt, and shrublands (Cytisus sp.) and pastures in the alpine level. These natural forest formations have been often replaced by other species of pine trees for forestry use, or directly removed to increase the extension of pastures for the livestock, an important industry in this rural area.

\section{Data and methods}

\subsection{Prado de las Pozas AWS and data from automatic weather stations network}

The reference meteorological station for this study is the Prado de las Pozas Automatic Weather Station (PLP AWS), located in the heart of the Gredos range, at 1947 m.a.sl. in a north-face $8 \%$ slope, $2.3 \mathrm{~km}$ away of the ridge and main divide of Tagus and Douro basins. It is managed by the CSIC-USAL (Spanish Research Council and University of Salamanca) research group and is equipped with sensors to measure temperature, relative humidity, wind speed and direction, global solar radiation, albedo, snow depth and precipitation. Precipitation is measured with an allprecipitation-type OTT PLuvio2 rain gauge (Fig. 1c) protected with single Alter wind shields, unheated, and with $1500-\mathrm{mm}$ capacity (the effective capacity is slightly lower, because wax paraffin to avoid evaporation, and antifreeze fluid are needed). The temporal resolution of precipitation measurements was $10 \mathrm{~min}$. Next to the OTT, we installed a Hobo tipping-bucket rain gauge, to check for consistency and accuracy in the measurements. No significant deviations in the records of the Hobo with respect to the OTT have been reported.

The other 36 meteorological stations considered in this study belong to different institutions or networks, including: a private weather station included in the Meteoclimatic network (https://www.meteoclimatic.net/perfil/ESCYL 0500000005634A); one of Inforiego network (http://www. inforiego.org/opencms/opencms/info_meteo/index.html); 4 belonging to AEMET (https://opendata.aemet.es/centrodede scargas/productosAEMET); 10 belonging to the automatic network of the Douro basin management agency $S A I H$ Duero (http://www.saihduero.es/risr/datos-tiempo-real); and lastly, 20 belonging to the automatic network of the Tagus basin management agency SAIH-Tajo (https://saihtajo. chtajo.es/). Summarizing, 23 are located within the Tagus river basin, and 14 within the Douro river basin (Fig. 1a), not far from the main basin divide. Average distance between stations is $8.4 \mathrm{~km}$, with maximum and minimum values of $19.9 \mathrm{~km}$ and $1.9 \mathrm{~km}$, respectively, covering and elevation range between 474 and $1960 \mathrm{~m}$.asl. The study period spans from October 2015 (when the PLP AWS became completely operational) to December 2019.

\subsection{Classification of heavy precipitation events}

There is not a universal definition for heavy precipitation, although the selection of a volumetric threshold per time unit is the more common method. For example, Groisman et al. (2012) defined "moderately heavy" precipitation events, as days with precipitation between 12.7 and $25.4 \mathrm{~mm} \mathrm{day}^{-1}$; "heavy" precipitation was between the range 25.4 and $76.2 \mathrm{~mm} \mathrm{day}^{-1}$; and "very heavy" precipitation as daily values over $76.2 \mathrm{~mm}$. In order to simplify and take just one threshold value, we defined "heavy precipitation events" (hereafter HPE) as the days where precipitation measured in PLP AWS was equal or larger than $50 \mathrm{~mm}$. This value represents the percentile 82 of the precipitation data series 
(records with daily value $>0.2 \mathrm{~mm}$ ) in PLP AWS and comprises a tradeoff between a high intensity of precipitation and a fair number of events that allow robust statistics to be done. A total 55 HPE where recorded during the study period, and the precipitation measured during those same days in the other 36 meteorological station was extracted from their data series for the comparative analysis. Of these, only 22 stations contained $100 \%$ of data during those events, and the number of events per station without data was $13.9 \%$ of the total (55 times 36). The maximum number of stations without data for any event was 10 .

From the precipitation recorded in each station and each HPE event, we computed averages, frequency, monthly distribution, and the similarity with respect to PLP AWS. The similarity analysis was based on the root square of summed squared differences between daily standardized precipitation amounts in each station with respect to daily standardized precipitation in PLP AWS.

\subsection{Weather types classification}

For each HPE, we estimated the synoptic configuration of the atmosphere over the Iberian Peninsula (IP) on the base of the automated circulation-typing scheme of Jenkinson and Collison (1977; hereafter JC method). The JC method can be applied in any mid-latitude zone. The grid-point is based on 16 points of daily sea level pressure (SLP) reanalysis data at a $5^{\circ}$ latitude by $10^{\circ}$ longitude (Jones et al. 1993; Linderson 2001). For this study, the area is bounded by $30.0^{\circ}$ and $50.0^{\circ} \mathrm{N}$, and $20.0^{\circ} \mathrm{W}$ and $10.0^{\circ} \mathrm{E}$, essentially centered over the IP (see maps in Cortesi et al. 2014 or MoránTejeda et al. 2019). The SLP dataset was obtained from the National Center for Environmental Prediction (NCEP) and the National Center for Atmospheric Research (NCAR) reanalysis project (https://psl.noaa.gov/data/gridded/data.ncep. reanalysis.html; Kalnay et al. 1996) for the 5-yr study period (2015-2019). The missing values were sparse and linearly interpolated from the surrounding grid-points (Chen 2000). Computation of weather types is specified in the supplementary information.

\subsection{Regression analysis}

A linear regression analysis was performed to assess the predictability of the spatial distribution of the HPE recorded at PLP AWS. For this, elevation, longitude and latitude from each of the 36 sites with weather station (see Sect. 3.1), excluding the station in PLP, were considered as independent variables and the $24-\mathrm{h}$ precipitation from each station as the dependent variable for multiple linear regressions. We tested and discarded other geographical variables (distance to the divide and bearing), due to colinearity with the abovementioned variables. A regression model was performed for every HPE in PLP AWS, giving a total of 55 regression models. The adjusted $R^{2}$ for each model informed of the quantity of variance in the spatial distribution of precipitation during heavy precipitation events that the aforementioned geographical variables were able to explain; whereas the beta-coefficients informed about the relative contribution of each variable in the predictability of the observed precipitation in PLP from neighboring stations. Selection of significant independent variables for the models followed a step-wise method based on the Akaike Information Criterium (AIC), and was performed with the stepAIC function of MASS R package (Venables et al., 2002).

\subsection{Weather forecast model}

Non-hydrostatic convection-permitting limited area weather models of high spatial resolution are used for operational short-range forecasts at National Weather Services of different countries (Bengtsson et al. 2017). These models allow representation of small-scale processes leading to obtain better simulations over complex terrain and during convection episodes than coarser resolution weather models with an evident improvement of rainfall forecasting (Clark et al. 2016). This represents a step forward in the simulation of atmospheric processes involved in orographic precipitation. Therefore, better rainfall forecasts are expected in mountain terrain prone to this type of precipitation.

To explore the performance of a high resolution weather model to forecast HPE, outputs from the Application of Research to Operations at Mesoscales (AROME) (Seity et al. 2011) weather model were used. AROME is a nonhydrostatic convection-permitting limited area model operationally used at Météo-France since December 2008 and it also covers partially the Iberian Peninsula, including the Central System. Five different runs are available every day $(00,03,06,12$, and 18UTC) with a forecast range up to $42 \mathrm{~h}$. AROME outputs of the 00UTC run from 2017 to 2019 (data from earlier dates were not available) at $0.025^{\circ}$ spatial resolution was collected from the Météo-France Open-Data Platform (http://donnespubliques.meteofrance.fr). Only 15 of the total of 55 HPE were thus available to be assessed with the AROME model.

Observed precipitation sums at the different AWS used in the study and the precipitation estimates for the corresponding grid point of AROME during HPE were compared. This allowed assessment of the ability of AROME to forecast both, precipitation in PLP during HPE and the spatial distribution of precipitation during HPE. A Taylor Diagram (Taylor 2001) was used for this assessment as it allows representing in a single plot three statistics (root mean square error, standard deviation and correlation coefficient) that summarize the fit between observations and model estimates. 


\section{Results}

\subsection{Heavy precipitation days in Prado de las Pozas AWS: temporal variability and association with weather types occurrence}

Average annual precipitation during the study period in PLP AWS was $2177 \mathrm{~mm}$, ranging from $3004 \mathrm{~mm}$ in 2016 to $1474 \mathrm{~mm}$ in 2017 . This annual values stand out from the volumes registered at the surrounding meteorological stations, which average $1127 \mathrm{~mm}$ per year, with maximum and minimum records of 2128 and $484 \mathrm{~mm}$ respectively in the study period.

a)

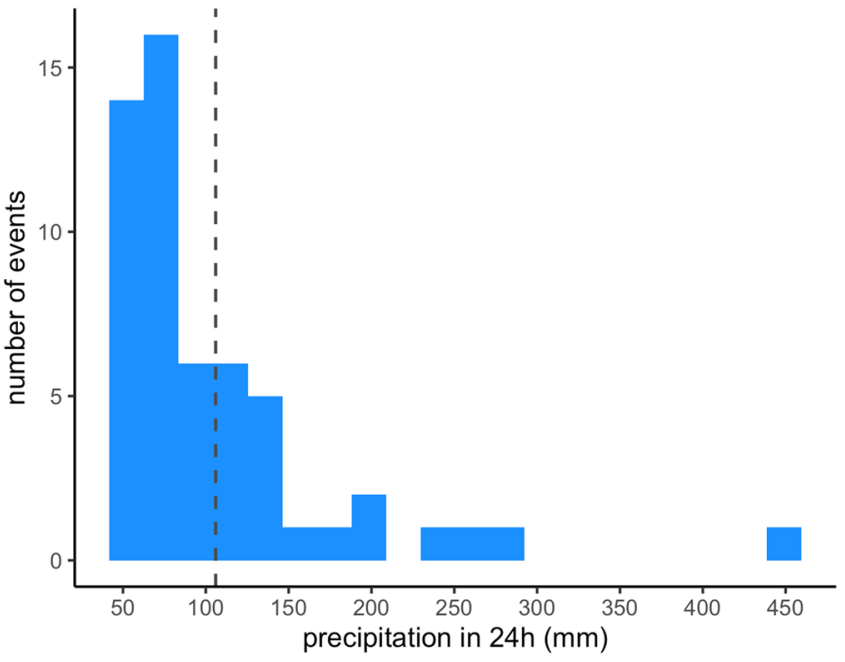

c)

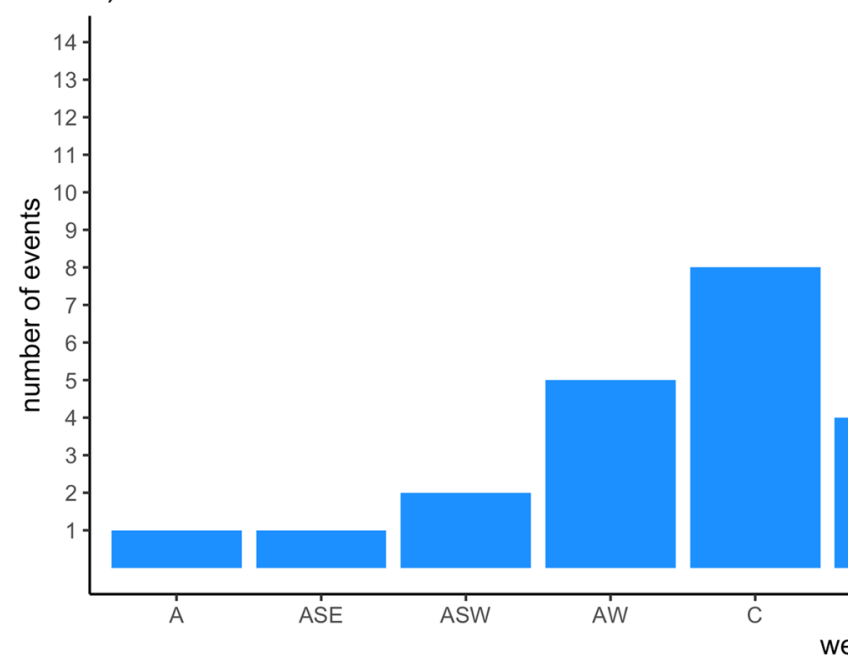

On average, $52 \%$ of annual precipitation in PLP AWS was registered during HPE, although in the wettest year, $75 \%$ of total precipitation was registered during 20 heavy precipitation days. During the study period (51 months), we identified 55 heavy precipitation days in PLP AWS, i.e., 1.08 events per month. The majority of events were situated within the range $50-100 \mathrm{~mm} \mathrm{day}^{-1}$ (Fig. 2a) but a fair number (20) registered values greater than $100 \mathrm{~mm}$, with one exceptional event of $447 \mathrm{~mm} \mathrm{day}^{-1}$ that occurred on December 2019. Most events occurred during autumn and spring months (Fig. 2b), with a frequency of more than 5 HPE per month. The weather types in which the majority of HPE occurred were advections from SW (25\%), W (14\%), S (10\%) and pure Cyclonic (14\%) weather type (Fig. 2c). Several events also occurred, however, under anticyclonic and

b)

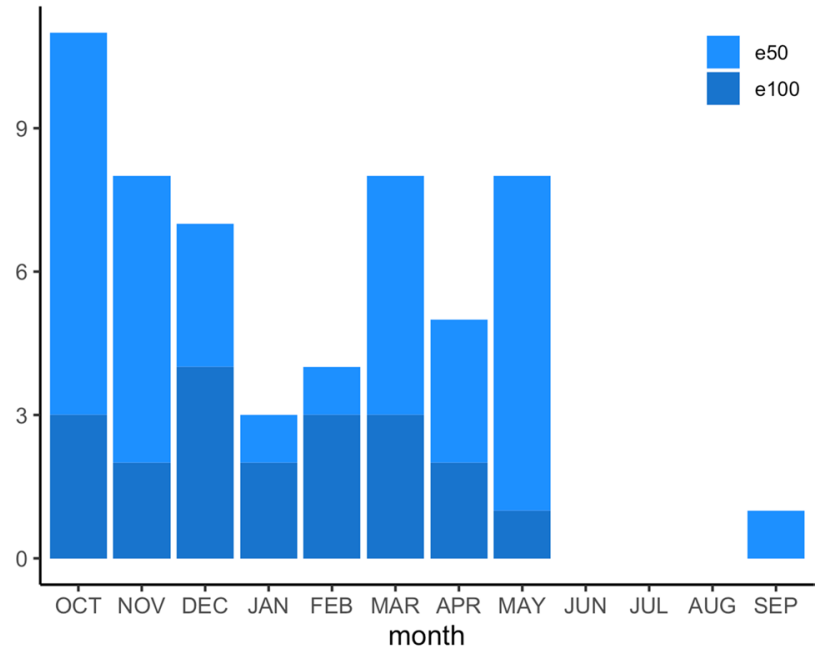

Fig. 2 Frequency of heavy precipitation events by (a) precipitation amount in $24 \mathrm{~h}$ (dotted line indicates the mean precipitation value for all events), (b) month of occurrence and (c) weather type. e50 indi- cates events with precipitation between 50 and $99 \mathrm{~mm} \mathrm{day}^{-1}$; e100 indicates events with precipitation equal or larger than $100 \mathrm{~mm} \mathrm{day}^{-1}$ 
"unclassified" weather types. Finally, no event was driven by advections with predominant $\mathrm{E}$ or $\mathrm{N}$ components.

\subsection{Spatial characteristics of HPE and regression analysis}

Figure 3 shows that HPE in PLP AWS are not spatially isolated events, as neighboring stations also register large precipitation amounts during the same events. The mean precipitation during HPE in PLP AWS was $104 \mathrm{~mm} \mathrm{day}^{-1}$, and the average of the other stations was $36 \mathrm{~mm} \mathrm{day}^{-1}$; this is a much smaller quantity; however, these values are biased towards PLP AWS because this is the reference station for defining HPE and there was certain amount of missing data in the other stations. Also, as we observe in Fig. 3a, there is high variability in the mean amounts of precipitation among stations. Stations showing larger values are generally located in the south flank of the mountain system and some stations in the north flank show very small amounts, with nearly none of the events with precipitation $>50 \mathrm{~mm} \mathrm{day}^{-1}$. Among the latter, some are located very close the PLP AWS (within a $15-\mathrm{km}$ radius), but this proximity did not mean large
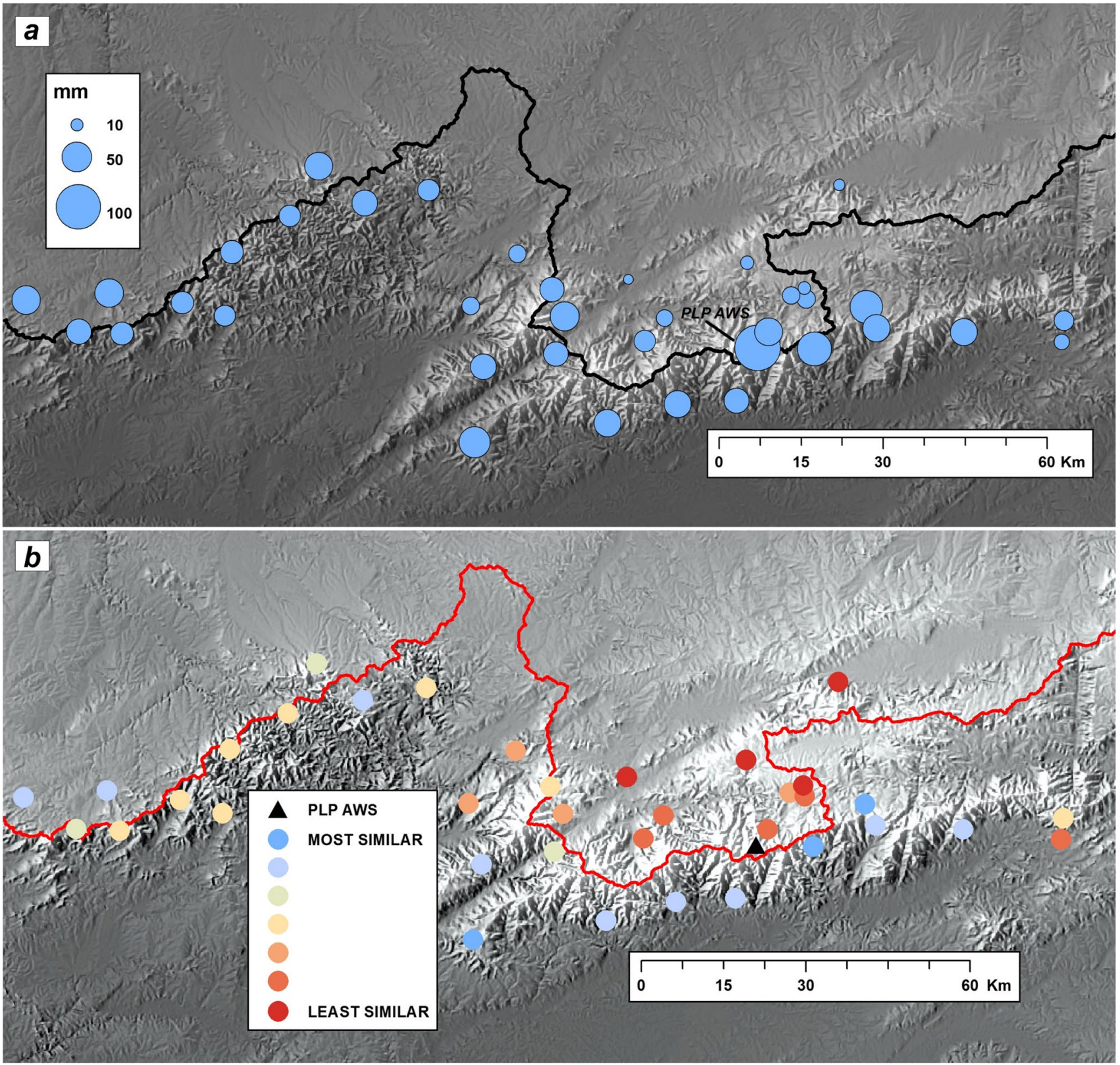

Fig. 3 Spatial characteristics of precipitation during HPE recorded in PLP AWS. a Mean precipitation amount during the HPE events; $\mathbf{b}$ Similarity between precipitation recorded in each station and PLP AWS during the HPE events 
precipitation amounts as one could expect. This reinforces the hypothesis of the orographic enhancement of precipitation amounts during these events that are mostly driven by advections of S, SW and W (see Sect. 4.1), that leave the north flank stations in the rain shadow of the mountain range. PLP AWS is also in the north flank, but very close $(2 \mathrm{~km})$ to the ridge, and therefore under the influence of the orographically enhanced clouds during such advective situations. This is confirmed by the similarity analysis performed for precipitation in each station with respect to PLP AWS (Fig. 3b). The most similar stations in terms of precipitation are those located in the south flank of the Gredos range, indicating that they register heavy precipitation during the same days and same atmospheric conditions. The least similar are, in contrast, those located in the north flank of the mountain range, including those located in the proximities of PLP AWS, and therefore in the rain shadow to south advections.

The regression analysis performed (Fig. 4) shows that the spatial variability of precipitation during HPE can be partially explained by the chosen geographical predictors, and precipitation amounts during these events in PLP are systematically underestimated by regression models. 13 out of the 55 regression models were discarded as no significant relationship was found between geographical drivers and heavy precipitation variability. Of the remaining 42 models, latitude was an explanatory variable in 33, longitude in 22, and elevation in 13 (Fig. 4a), but the quantity of variance explained by the combined predictors was generally low (mean $\mathrm{R}^{2}$ of the 43 models $=0.21 \pm 0.13$, Fig. $4 \mathrm{~b}$ ). Beta coefficients of Latitude and Longitude show mostly negative values (Fig. 4a), indicating a predominant geographic direction in the magnitude of precipitation (larger values towards more southern and western locations), therefore in the windward side of the mountain range to prevailing southwest flows. Elevation shows mostly positive coefficients indicating an increase of precipitation magnitude with elevation (Fig. 4a), but only in 13 models. There is no statistical relationship between the magnitude of the precipitation event and the predictive capacity of the linear models (Fig. 4b). Finally, the variability in observed heavy precipitation values for PLP is well predicted by the regression models (Fig. 4c) but there is a great underestimation in the magnitude (of $60 \%$ average for each event), indicating the difficulty to predict precipitation during intense events on the basis of regression techniques.

\subsection{Predictability of heavy precipitation by AROME model}

The weather forecast AROME model worked much better than geographically-based regression models for predicting precipitation values in the study area during the most recent HPE (2018-2019) in PLP AWS. Figure 5 shows the comparison between observed and forecasted precipitation during three selected HPE, including the most intense event, with $447 \mathrm{~mm} \mathrm{day}^{-1}$ in PLP AWS. The AROME model did overestimate or underestimate precipitation values depending on the event and on the weather station (see different colors of dots with respect to pixels in Fig. 5), although at some points, it also showed pretty similar values to that of observations in weather stations. In order to summarize the performance of the AROME model, we have constructed a Taylor diagram (Fig. 6a), which shows three statistics of model's predictions versus observations in the 37 weather stations for the common 15 HPE. $\mathrm{R}^{2}$ values were between 0.6 and 0.9 during most events (only two events showed $\mathrm{R}^{2}<0.4$ ), indicating a generalized good performance of the model for predicting the spatial variability of precipitation. However,
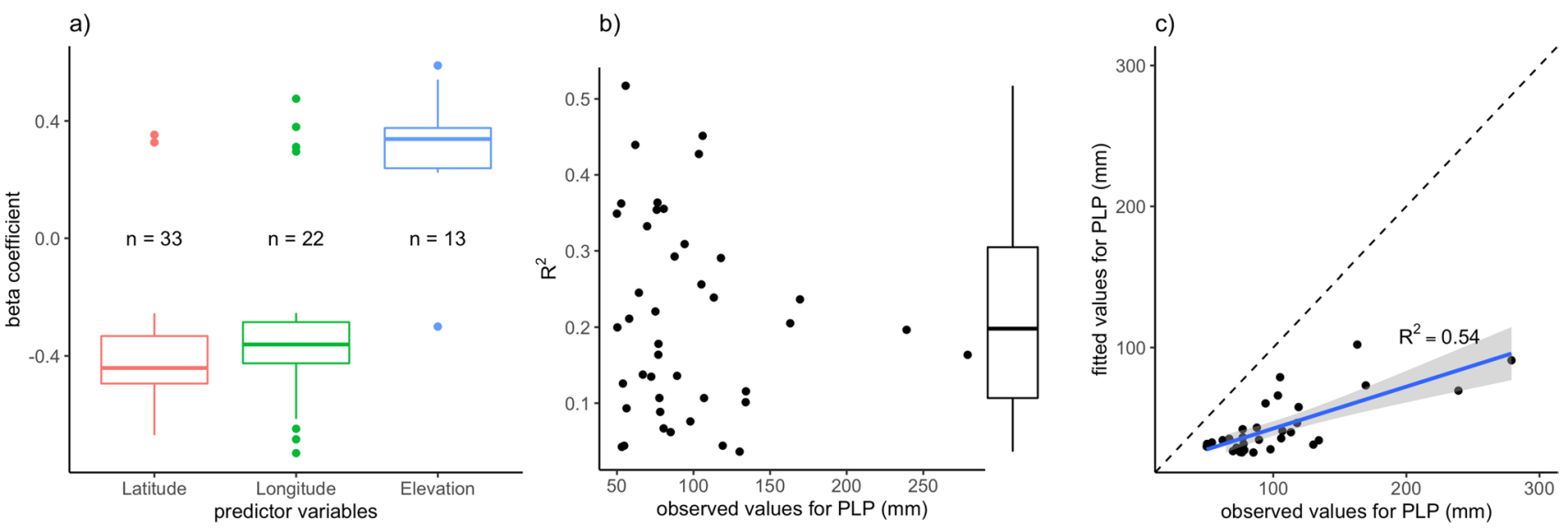

Fig. 4 Summary of regression analysis for the 42 significant linear models. a Beta coefficients for the geographical predictors: median (thick line), interquartile range (box), $10^{\text {th }}$ and $90^{\text {th }}$ percentiles (whiskers) and outliers (dots); b Observed values for HPE in PLP vs

$\mathrm{R}^{2}$ of the regression models; boxplot in the right shows the median and variability of the $42 \mathrm{R}^{2}$ values; c) Observed values for HPE vs fitted values in PLP with regression line (blue) and confidence intervals (grey shade). Dashed line indicates the 1:1 slope 
Fig. 5 Amounts of precipitation recorded (dots) and forecasted by the AROME model (pixels) during three selected HPE in PLP AWS
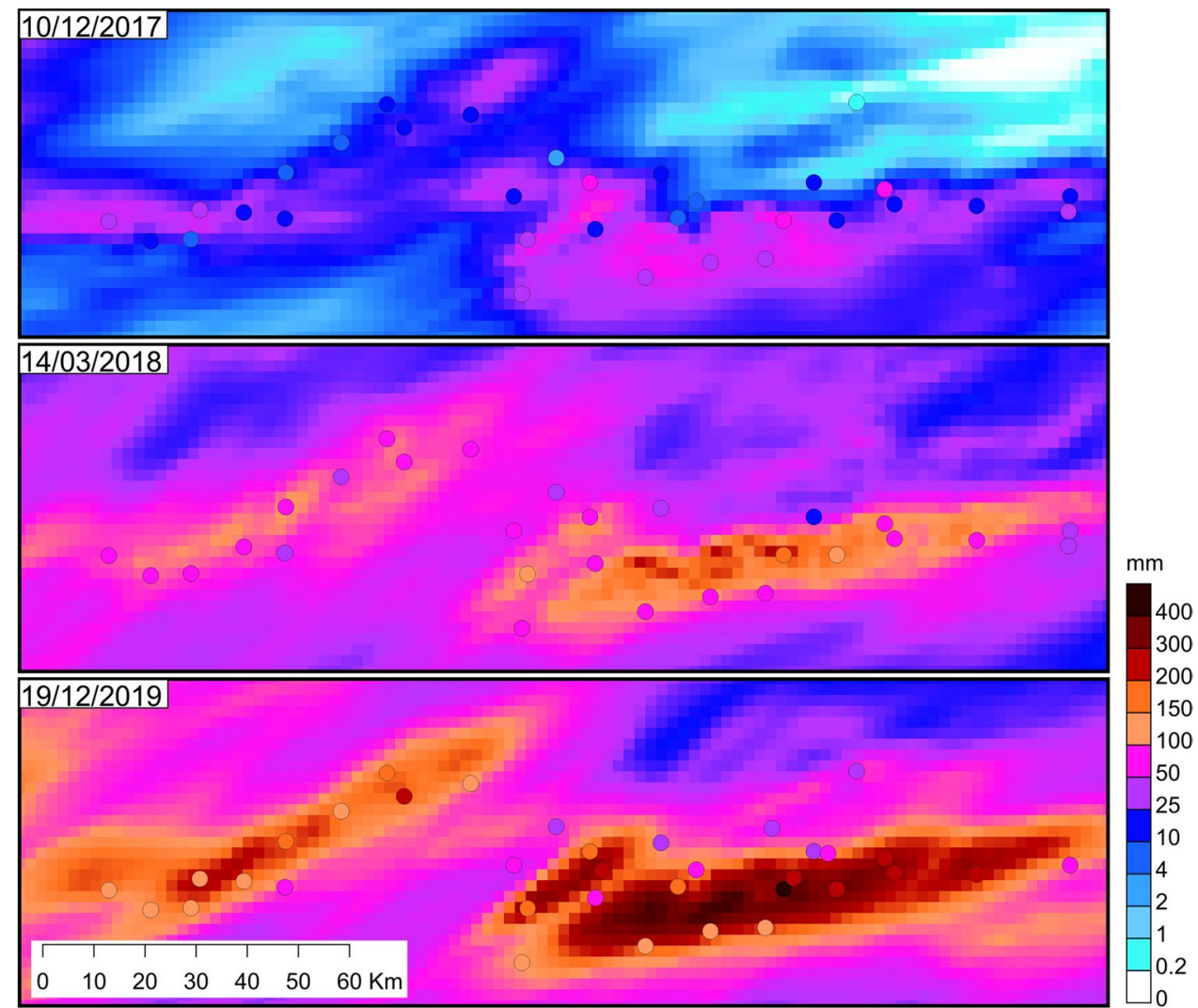

the standard deviation of model estimates are mostly lower than standard deviation of observations, which indicates a slight underestimation in the predicted spatial variance of precipitation during HPE. Model estimates for most events show normalized root mean squared error (RMSE divided by the standard deviation of observations) values $<1$ in most cases; this indicates that the spatial variability of errors (i.e. variance of precipitation during HPE not explained by the model) is lower than the variability of observations, indicating a generally good predictability; moreover, the normalized RMSE is not related to the magnitude of the event. When looking at the ability of AROME to predict precipitation in PLP AWS during the HPE (Fig. 6b), we confirm a fair performance, with a very good correlation $\left(\mathrm{R}^{2}=0.87\right)$ between observations and estimates, and an underestimation of $26 \%$, while for the rest of stations AROME overestimates an average $13 \%$ (not shown).

\section{Discussion}

It is widely known that mountain terrain usually records larger amounts of precipitation than lowlands or plain surrounding areas through different mechanisms that enhance formation of precipitating clouds when air flows over or around the mountain (see review in Houze 2012). However, accurate quantification of precipitation amounts over mountainous terrain is still challenging because of the spatial variability derived from the complexity of the terrain. Such variability would require more dense monitoring networks than in plain terrain, but the reality is the opposite, and normally mountainous terrain is largely underrepresented in the National Weather Services of the countries (Derin et al. 2016; Lundquist et al. 2019) because of the difficult access to high elevation sites and the high costs of maintenance. Such is the case of Spain (Serrano-Notivoli et al. 2017), and the result of this is that the different products (maps, gridded databases) elaborated from the data of observational networks may underrepresent precipitation in mountains, and this can lead to biased results in climatological, hydrological or ecological research. A prove of this is the uncertainty about the location of the pluviometric maximum in Spain that has always been a matter of geographic discussion. According to the climatic Atlas by AEMET (2011), the city of Vigo in the northwest Atlantic façade recorded the greatest amounts (1919 $\mathrm{mm}$ year $^{-1}$ ) in the Iberian Peninsula during the 1971-2000 period. On the other hand, the Grazalema mountain range in Andalusia has been always pointed out as one of the rainiest places in Spain, with annual amounts surpassing $2000 \mathrm{~mm}$. This is mainly explained by its location windward to the southwest fronts entering the Iberian Peninsula by the Gulf of Cadiz (Pita 2003) and the orographic 
a)

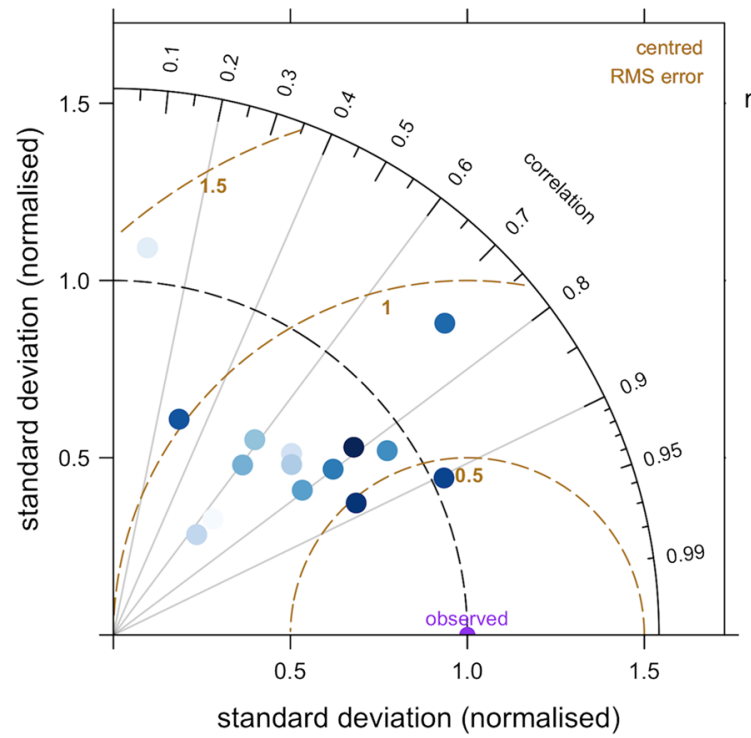

Fig. 6 Performance of AROME model for predicting HPE. a Taylor Diagram showing the $\mathrm{R}^{2}$, normalized root mean square error (i.e. RMSE divided by the standard deviation of observations), and normalized standard deviation of model's predictions versus observations in the 37 weather stations in each of the common HPE $(n=15$,

effect. Capel-Molina (1995) observed a pluviometric maximum of $2660 \mathrm{~mm}$ year $^{-1}$ in the westernmost sector of the Pyrenees - Articutza station - close to the Atlantic coast, for the 1961-1990 period. For our study area, there is discrepancy among authors. Lautensach (1967) estimated that in the Almanzor peak (very close to the PLP AWS) the annual rainfall was higher than $2000 \mathrm{~mm}$. García-Rodríguez et al. (1984) affirmed that the maximum annual precipitation for the entire Iberian Peninsula presumably occurs at the nearby summit of La Ceja, at 2425 m.asl., with estimated volumes of about $3500 \mathrm{~mm}$ per year; however this estimation was a result of geostatistical extrapolations and is subject to uncertainty. Capel-Molina (1995) only observed maximums of about $1800 \mathrm{~mm}_{\text {year }}{ }^{-1}$ in Gredos mountains, but more recent studies (García et al. 2017) confirmed large areas above the 2000 isohyet. Our goal was not to contradict the previous studies, or set a new location for the pluviometric maximum, but, even if our study period is not long enough to extract significant long-term statistics, we can confirm the Gredos mountains as one of the rainiest locations in Spain. The most relevant matter in this discussion and the discrepancy of results is not the actual location of the rainiest place in Spain, but the large uncertainty in the spatial variability of precipitation in mountainous terrain, and the aforementioned difficulty to measure actual precipitation amounts with the conventional meteorological monitoring networks. Our results demonstrate that a rain gauge specifically designed for mountain weather and located near the b)

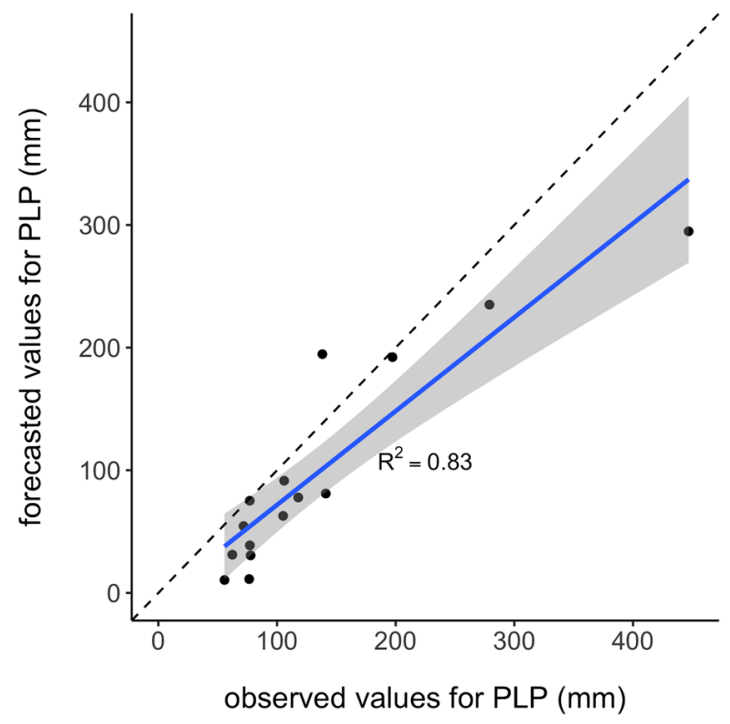

color dots). b Forecasted values of precipitation vs observed values in PLP during heavy precipitation events $(n=15)$, with regression line (blue) and confidence intervals (gray shade). Dashed line indicates the $1: 1$ slope

fringe of a mountain range can record exceptional amounts of precipitation compared to nearby regular rain gauges of institutional monitoring networks at less elevated locations.

In our study, we focused on the most intense precipitation events for several reasons: because of their potential to cause risks, because conventional tipping bucket rain gauges may not measure well high intensities of precipitation, and because weather models normally fail in predicting the location and precipitation amounts during such events. We counted more than one heavy precipitation event per month at our study site, although most events occurred during autumn and spring months, with a frequency of more than five events per month. The most common weather types in which HPE occurred were advections from SW, W, S and pure Cyclonic. These are also the weather types in which most autumn-to-spring precipitation occurs in the western Iberian Peninsula, where synoptic-scale baroclinic systems associated to the Atlantic polar front enter from the W, SW, NW or even from the S depending on the position of the low pressure center (Serrano et al. 1999). This reinforces the idea that the HPE registered in Gredos mountains are not spatially isolated events, as the similarity analysis with other meteorological stations in the surrounding area confirm. However, the larger magnitude of precipitation in the PLP AWS compared to surrounding stations confirmed its exceptional nature. Moreover, there were also HPE that occurred under anticyclonic and "unclassified" weather types. This is not anomalous in mountain terrain and may be explained 
by convergence-driven convection over the mountain fringe when upslope thermal winds from the hillsides develop during daytime under otherwise calmed weather conditions; this mechanism when combined with instability induced by a cold upper atmosphere layer may induce formation of thunderstorms and intense precipitation (Houze 2012; Linder et al. 1999; Schaefer 1986).

As abovementioned, the precipitation registered both annually, and during HPE in PLP AWS was exceptional in the regional context of the surrounding meteorological stations. Our results suggest that its location, close to the mountain fringe at 1947 m.asl., allowed us to record the orographic enhancement of precipitation under the synopticscale conditions above described, and underline the great effect of orographic barrier of this mountain range forcing uplift of wet air masses coming from the Atlantic. The linear regressions performed show that latitude, longitude, and elevation partially explained the spatial variability of precipitation during HPE. Larger precipitation values were found towards more southern and western locations, therefore in the windward side of the mountain range to prevailing $\mathrm{W}$ and SW flows. This reinforces the hypothesis that HPE are result from orographic uplift of air masses; southern and westernmost locations recorded the largest amounts of precipitation, and these coincide with the first mountains of Central System that air masses encounter when they enter the Iberian Peninsula. This makes air masses lose humidity as they travel northeast and therefore precipitation potential becomes lower. Elevation shows mostly positive coefficients indicating increasing precipitation with elevation, but it was a significant explanatory variable in linear regressions of only 13 of the 55 events. As we previously noted, relationship between precipitation and elevation is not always linear, and this is most likely due to the fact that precipitation formation as a result of an upward motion is generally more effective at lower elevations, because the saturation vapor pressure of the atmosphere decreases exponentially with temperature and hence with height (Houze 2012). There may be as well other physical mechanisms that explain the non-linearity (e.g. seeder-feeder clouds, or availability of condensation nuclei), which we cannot account for with our methodology.

In any case, the linear models always underestimated (average of $60 \%$ ) precipitation in PLP AWS, most likely because there is not enough information at high elevations, just our AWS. Large amounts of variability remain unexplained by geographical linear models, which confirm the complexity to predict precipitation in complex topography terrain on the basis of geographic variables and the necessity to improve the monitoring network and the forecast tools. In this sense, our last goal was to assess the ability of a high resolution weather forecast model to predict the occurrence of HPE. The precipitation estimates by AROME model showed much better resemblance with observations during HPE than the geographical linear models. AROME model captured better the orographic enhancement of precipitation and the spatial variability of precipitation. It did, however, underestimate the volumes registered at PLP (26\%), and slightly overestimate (13\%) precipitation in the rest of stations, which confirms the exceptional nature of precipitation in PLP even for a convection-permitting weather model, but also indicates that the spatial resolution of the model $(2 \mathrm{~km})$ may still be too coarse to accurately simulate specific meteorological processes that occur in the complex orography of mountainous terrain Similar results have been recently found in different environments when predicting heavy precipitation events by AROME model. Caillaud et al. (2021) observed that AROME was able to represent extreme precipitation in the northwestern Mediterranean, including the southern French Alps, at daily and hourly scale; although it did underestimate precipitation for very high intensities (over $200 \mathrm{~mm} \mathrm{day}^{-1}$ ). El Khalki et al. (2020) confirmed the good performance of AROME model for predicting intense precipitation amounts resulting in flash-floods in Morocco in comparison with other forecast models. They both highlighted that the high-resolution, and the explicitly resolved deep convection, represent clear improvements for intense precipitation forecast compared to other models. These improvements in the new generation of models will help understand the occurrence of these HPE as well as designing better monitoring networks by including areas where precipitation anomalies are not well represented.

\section{Conclusions}

This research demonstrates the importance of monitoring high mountain areas to accurately quantify spatial and temporal amounts of precipitation over complex terrain, and to locate and categorize heavy precipitation events with potential hydrological impacts.

The installation of an all-type-of-precipitation rain gauge near the divide of Gredos range in the Central System allowed recording exceptional volumes of precipitation at both, annual and event scales, confirming this location as one of the precipitation hotspots of Spain.

The weather types in which most heavy precipitation events took place in Gredos - pure cyclonic and advections from $\mathrm{W}, \mathrm{SW}$ and $\mathrm{S}$ - along with volumes recorded in nearby meteorological stations, confirm that the majority of events were not spatially isolated. The exceptional nature of precipitation observed in the highest slopes of Gredos can be explained by the orographic effect of the mountain range to precipitating clouds under the aforementioned synoptic situations. 
The predictability of heavy precipitation events was assessed by means of linear regressions with geographical variables as well as with the high resolution, convectionpermitting weather forecast AROME model. The geographical characteristics of meteorological stations - latitude, longitude and elevation - partially explained the spatial variability of precipitation during heavy precipitation events, confirming the orographic effect on precipitation. However, large amounts of variance remained unexplained and precipitation volumes were largely underestimated by linear models. AROME captured better the spatial variability of precipitation during extreme events, although it did underestimate as well the largest volumes registered in our rain gauge. This confirms the complexity of predicting precipitation in complex terrain, but also the usefulness of the last generation of weather models to improve the knowledge of climatic extremes and the necessity to improve the monitoring networks to better represent precipitation at high elevations.

Supplementary Information The online version contains supplementary material available at https://doi.org/10.1007/s00704-021-03791-x.

Acknowledgements We are thankful to Roberto Muñoz García for providing the data from his meteorological station at Hoyos del Espino, as well as to colleagues and friends that helped during the installation and maintenance of PLP AWS

Author contribution Enrique Morán-Tejeda: Resources, Methodology, Conceptualization, Formal Analysis, Visualization, Writing-Original draft. José Manuel Llorente-Pinto: Resources, Conceptualization, Formal Analysis, Visualization, Writing-Original draft. Antonio Ceballos-Barbancho: Resources, Conceptualization, Data curation, Project administration, Writing-Review editing. Miquel Tomás-Burguera: Formal Analysis, Writing-Original draft. César Azorín-Molina: Resources, Methodology, Writing-Review editing. Esteban Alonso-González: Software, Formal Analysis. Jesús Revuelto: Software, Writing-Review editing. Javier Herrero: Resources, Writing-Review editing. Juan Ignacio López-Moreno: Resources, Methodology, Conceptualization, Formal Analysis, Project administration, Funding acquisition, WritingReview editing.

Funding Open Access funding provided thanks to the CRUE-CSIC agreement with Springer Nature. This study was funded by the Spanish Ministry of Economy and Competitiveness projects CGL201127536/HID (HIDRONIEVE), CGL2014-52599-P (IBERNIEVE) and CGL2017-82216-R (HIDROIBERNIEVE). C. A-M. was supported by the Ramon y Cajal Fellowship (RYC-2017-22830).

Data availability Meteorological information of stations used in the study were available in Meteoclimatic network at https://www.meteo climatic.net/perfil/ESCYL0500000005634A (private data, available upon request); Inforiego network at http://www.inforiego.org/opencms/ opencms/info_meteo/index.html; AEMET at https://opendata.aemet.es/ centrodedescargas/productosAEMET; the Douro basin management agency $S A I H$-Duero at http://www.saihduero.es/risr/datos-tiempo-real and the Tagus basin management agency SAIH-Tajo at https://saiht ajo.chtajo.es/.

Sea level pressure data for calculating weather types were downloaded from the National Center for Atmospheric Research (NCAR) reanalysis project at, https://psl.noaa.gov/data/gridded/data.ncep.reana lysis.html.

AROME model outputs are available to download for the current day at https://donneespubliques.meteofrance.fr. The historical data are archived by MeteoFrance.

The meteorological data from the Prado de las Pozas Automatic Weather Station is available from the corresponding author upon reasonable request and acknowledgement.

Code availability Calculations were done using R software standard functions such as $\operatorname{lm}()$ for linear regressions, or TaylorDiagram(), from openair package, for the elaboration of the Taylor diagram in Fig. 6. Maps were done with ArcGIS ${ }^{\circledR}$ software.

\section{Declarations}

Ethics approval and consent to participate Not applicable.

Consent for publication Not applicable.

Conflict of interest The authors declare no competing interests.

Open Access This article is licensed under a Creative Commons Attribution 4.0 International License, which permits use, sharing, adaptation, distribution and reproduction in any medium or format, as long as you give appropriate credit to the original author(s) and the source, provide a link to the Creative Commons licence, and indicate if changes were made. The images or other third party material in this article are included in the article's Creative Commons licence, unless indicated otherwise in a credit line to the material. If material is not included in the article's Creative Commons licence and your intended use is not permitted by statutory regulation or exceeds the permitted use, you will need to obtain permission directly from the copyright holder. To view a copy of this licence, visit http://creativecommons.org/licenses/by/4.0/.

\section{References}

Abermann J, Eckerstorfer M, Malnes E, Hansen BU (2019) A large wet snow avalanche cycle in West Greenland quantified using remote sensing and in situ observations. Nat Hazards 97:517-534. https:// doi.org/10.1007/s11069-019-03655-8

AEMET, 2011. Atlas Climático Ibérico. Temperatura del aire y precipitación (1971-2000). Instituto de Meteorologia de Portugal y Agencia Estatal de Meteorología, Ministerio de Medio Ambiente y Medio Rural y Marino, Madrid.

Barry RG (2008) Mountain weather and climate, 3rd edn. Cambridge University Press, Cambridge

Barton Y, Sideris IV, Raupach TH, Gabella M, Germann U, Martius O (2020) A multi-year assessment of sub-hourly gridded precipitation for Switzerland based on a blended radar-rain-gauge dataset. Int J Climatol 40:5208-5222. https://doi.org/10.1002/joc.6514

Bengtsson L, Andrae U, Aspelien T, Batrak Y, Calvo J, de Rooy W, Gleeson E, Hansen-Sass B, Homleid M, Hortal M, Ivarsson KI, Lenderink G, Niemelä S, Nielsen KP, Onvlee J, Rontu L, Samuelsson P, Muñoz DS, Subias A, Tijm S, Toll V, Yang X, Køltzow MØ (2017) The HARMONIE-AROME model configuration in the ALADIN-HIRLAM NWP system. Mon Weather Rev 145:1919_ 1935. https://doi.org/10.1175/MWR-D-16-0417.1

Browning KA, Hill FF (1981) Orographic rain. Weather 36:326-328. https://doi.org/10.1002/j.1477-8696.1981.tb05354.x 
Burcea S, Cică R, Bojariu R (2019) Radar-derived convective storms' climatology for the Prut River basin: 2003-2017. Nat Hazards Earth Syst Sci 19:1305-1318. https://doi.org/10.5194/ nhess-19-1305-2019

Caillaud C, Somot S, Alias A, Bernard-Bouissières I, Fumière Q, Laurantin O, Seity Y, Ducrocq V (2021) Modelling Mediterranean heavy precipitation events at climate scale: an object-oriented evaluation of the CNRM-AROME convection-permitting regional climate model. Clim Dyn 1:3. https://doi.org/10.1007/ s00382-020-05558-y

Capel-Molina JJ (1995) Mapa pluviométrico de España peninsular y Baleares en el periodo internacional 1961-1990. Investig Geográficas 13:29-46

Chen D (2000) A monthly circulation climatology for Sweden and its application to a winter temperature case study. Int J Climatol 20:1067-1076. https://doi.org/10.1002/1097-0088(200008)20: 10\%3c1067::AID-JOC528\%3e3.0.CO;2-Q

Clark P, Roberts N, Lean H, Ballard SP, Charlton-Perez C (2016) Convection-permitting models: a step-change in rainfall forecasting. Meteorol Appl. https://doi.org/10.1002/met.1538

Colle, B.A., Smith, R.B., Wesley, D.A., 2013. Theory, Observations, and Predictions of Orographic Precipitation. Springer, Dordrecht. 291-344. https://doi.org/10.1007/978-94-007-4098-3_6

Cortesi N, Gonzalez-Hidalgo JC, Trigo RM, Ramos AM (2014) Weather types and spatial variability of precipitation in the Iberian Peninsula. Int J Climatol 34:2661-2677. https://doi.org/10. 1002/joc. 3866

del Moral A, del Llasat M, C., Rigo, T., (2020) Connecting flash flood events with radar-derived convective storm characteristics on the northwestern Mediterranean coast: knowing the present for better future scenarios adaptation. Atmos Res 238:104863. https://doi. org/10.1016/j.atmosres.2020.104863

del Moral A, Rigo T, Llasat MC (2018) A radar-based centroid tracking algorithm for severe weather surveillance: identifying split/merge processes in convective systems. Atmos Res 213:110-120. https:// doi.org/10.1016/j.atmosres.2018.05.030

Derin Y, Anagnostou E, Berne A, Borga M, Boudevillain B, Buytaert W, Chang CH, Delrieu G, Hong Y, Hsu YC, Lavado-Casimiro W, Manz B, Moges S, Nikolopoulos EI, Sahlu D, Salerno F, Rodríguez-Sánchez JP, Vergara HJ, Yilmaz KK (2016) Multiregional satellite precipitation products evaluation over complex terrain. J Hydrometeorol 17:1817-1836. https://doi.org/10.1175/ JHM-D-15-0197.1

Durán L, Sánchez E, Yagüe C (2013) Climatology of precipitation over the Iberian Central System mountain range. Int J Climatol 33:2260-2273. https://doi.org/10.1002/joc.3602

El Khalki EM, Tramblay Y, Amengual A, Homar V, Romero R, Saidi MEM, Alaouri M (2020) Validation of the AROME, ALADIN and WRF meteorological models for flood forecasting in Morocco. Water 12:437. https://doi.org/10.3390/w12020437

Ferrari F, Cassola F, Tuju PE, Stocchino A, Brotto P, Mazzino A (2020) Impact of model resolution and initial/boundary conditions in forecasting flood-causing precipitations. Atmosphere (basel) 11:592. https://doi.org/10.3390/atmos11060592

Frei C, Schär C (1998) A precipitation climatology of the Alps from high-resolution rain-gauge observations. Int J Climatol 18:873900. https://doi.org/10.1002/(SICI)1097-0088(19980630)18:8\% 3c873::AID-JOC255\%3e3.0.CO;2-9

García-Rodríguez, J.A., Puerto-Martín, A., Rodríguez-González, R., 1984. Aspectos ecológicos de la provincial de Salamanca. Salamanca.

García MM, Martín JR, Sánchez Llorente JM, Soriano LR, de Pablo Dávila F (2017) Intense precipitation events in the Central Range of the Iberian Peninsula. Nat Hazards Earth Syst Sci 17:22892300. https://doi.org/10.5194/nhess-17-2289-2017
Germann U, Galli G, Boscacci M, Bolliger M (2006) Radar precipitation measurement in a mountainous region. Q J R Meteorol Soc 132:1669-1692. https://doi.org/10.1256/qj.05.190

Germann, U., Joss, J., 2004. Operational Measurement of Precipitation in Mountainous Terrain. Springer, Berlin, Heidelberg. 52-77. https://doi.org/10.1007/978-3-662-05202-0_2

Groisman PY, Knight RW, Karl TR (2012) Changes in intense precipitation over the Central United States. J Hydrometeorol 13:47-66. https://doi.org/10.1175/JHM-D-11-039.1

Houze, R.A., 2012. Orographic effects on precipitating clouds. Rev. Geophys. 50https://doi.org/10.1029/2011RG000365

Jenkinson, A.F., Collison, F.P., 1977. An initial climatology of Gales over the North Sea. Synop. Climatol. Branch Memo. No. 62, Meteorol. Off. Brac.

Jones PD, Hulme M, Briffa KR (1993) A comparison of Lamb circulation types with an objective classification scheme. Int J Climatol 13:655-663. https://doi.org/10.1002/joc.3370130606

Kalnay E, Kanamitsu M, Kistler R, Collins W, Deaven D, Gandin L, Iredell M, Saha S, White G, Woollen J, Zhu Y, Chelliah M, Ebisuzaki W, Higgins W, Janowiak J, Mo KC, Ropelewski C, Wang J, Leetmaa A, Reynolds R, Jenne R, Joseph D (1996) The NCEP/NCAR 40-year reanalysis project. Bull Am Meteorol Soc 77:437-471. https://doi.org/10.1175/1520-0477(1996)077\% 3c0437:TNYRP\%3e2.0.CO;2

Khanal AK, Delrieu G, Cazenave F, Boudevillain B (2019) Radar remote sensing of precipitation in high mountains: detection and characterization of melting layer in the grenoble valley, french Alps. Atmosphere (basel) 10:784. https://doi.org/10.3390/ ATMOS 10120784

Lautensach H (1967) Geografía de España y Portugal. Vicens-Vives, Barcelona

Linder W, Schmid W, Schiesser HH (1999) Surface winds and development of thunderstorms along southwest-northeast oriented mountain chains. Weather Forecast 14:758-770. https://doi.org/ 10.1175/1520-0434(1999)014\%3c0758:SWADOT\%3e2.0.CO;2

Linderson M-L (2001) Objective classification of atmospheric circulation over southern Scandinavia. Int J Climatol 21:155-169. https:// doi.org/10.1002/joc.604

Lorenzo-Lacruz J, Amengual A, Garcia C, Morán-Tejeda E, Homar V, Maimó-Far A, Hermoso A, Ramis C, Romero R (2019) Hydrometeorological reconstruction and geomorphological impact assessment of the October 2018 catastrophic flash flood at Sant Llorenç, Mallorca (Spain). Nat Hazards Earth Syst Sci 19:25972617. https://doi.org/10.5194/nhess-19-2597-2019

Lundquist J, Hughes M, Gutmann E, Kapnick S (2019) Our skill in modeling mountain rain and snow is bypassing the skill of our observational networks. Bull Am Meteorol Soc 100:2473-2490. https://doi.org/10.1175/BAMS-D-19-0001.1

Melillo M, Gariano SL, Peruccacci S, Sarro R, Mateos RM, Brunetti MT (2020) Rainfall and rockfalls in the Canary Islands: assessing a seasonal link. Nat Hazards Earth Syst Sci 20:2307-2317. https:// doi.org/10.5194/nhess-20-2307-2020

Molini A, Lanza LG, La Barbera P (2005) The impact of tipping-bucket raingauge measurement errors on design rainfall for urban-scale applications. Hydrol Process 19:1073-1088. https://doi.org/10. 1002/hyp.5646

Morán-Tejeda E, Fassnacht SR, Lorenzo-Lacruz J, López-Moreno JI, García C, Alonso-González E, Collados-Lara AJ (2019) Hydrometeorological characterization of major floods in Spanish mountain rivers. Water (switzerland) 11:2641. https://doi.org/10.3390/ W11122641

Moya-Álvarez A, Gálvez J, Holguín A, Estevan R, Kumar S, Villalobos E, Martínez-Castro D, Silva Y (2018) Extreme rainfall forecast with the WRF-ARW model in the Central Andes of Peru. Atmosphere (basel) 9:362. https://doi.org/10.3390/atmos9090362 
Naranjo-Barea AJ, Rodrigo-Comino J, Senciales-González JM (2017) Estimation of the Venturi effect as a leading factor of pluviometry in the Grazalema Mountain. Pirineos 172:33. https://doi.org/10. 3989/pirineos.2017.172008

Ninyerola M, Pons X, Roure JM (2007) Monthly precipitation mapping of the Iberian Peninsula using spatial interpolation tools implemented in a Geographic Information System. Theor Appl Climatol 89:195-209. https://doi.org/10.1007/s00704-006-0264-2

Ninyerola M, Pons X, Roure JM (2005) Atlas climático digital de la Península Ibérica: metodología y aplicaciones en bioclimatología y geobotánica. Universitat Autònoma de Barcelona, Bellaterra

Nitu, R., Roulet, Y.-A., Wolff, M., Earle, M., Reverdin, A., Smith, C., Kochendorfer, J., Morin, S., Rasmussen, R., Wong, K., Alastrué, J., Arnold, L., Baker, B., Buisán, S., Collado, J.L., Colli, M., Collins, B., Gaydos, A., Hannula, H.-R., Hoover, J., Joe, P., Kontu, A., Laine, T., Lanza, L., Lanzinger, E., Lee, G.W., Lejeune, Y., Leppänen, L., Mekis, E., Panel, J.-M., Poikonen, A., Ryu, S., Sabatini, F., Theriault, J., Yang, D., Genthon, C., Van Den Heuvel, F., Hirasawa, N., Konishi, H., Motoyoshi, H., Nakai, S., Nishimura, K., Senese, A., Yamashita, K., 2019. Instruments and Observing Methods WMO Solid Precipitation Intercomparison Experiment (SPICE) (2012-2015). Agencia Estatal de Meteorología.

Ochoa-Rodriguez S, Wang LP, Willems P, Onof C (2019) A review of radar-rain gauge data merging methods and their potential for urban hydrological applications. Water Resour Res. https://doi. org/10.1029/2018WR023332

Ogrin M, Kozamernik E (2020) Vertical precipitation gradients: a case study of Alpine valleys of northwestern Slovenia. Theor Appl Climatol 140:401-409. https://doi.org/10.1007/s00704-019-03051-z

Peter JR, Manton MJ, Potts RJ, May PT, Collis SM, Wilson L (2015) Radar-derived statistics of convective storms in southeast Queensland. J Appl Meteorol Climatol 54:1985-2008. https://doi.org/10. 1175/JAMC-D-13-0347.1

Pita, M.F., 2003. El clima de Andalucía, in: López-Ontiveros, A. (Ed.), Geografía de Andalucía. Ariel. 137-173.

Ramos AM, Trigo RM, Liberato MLR, Tomé R (2015) Daily precipitation extreme events in the Iberian Peninsula and its association with atmospheric rivers. J Hydrometeorol 16:579-597. https://doi. org/10.1175/JHM-D-14-0103.1

Rasmussen R, Baker B, Kochendorfer J, Meyers T, Landolt S, Fischer AP, Black J, Thériault JM, Kucera P, Gochis D, Smith C, Nitu R, Hall M, Ikeda K, Gutmann E (2012) How well are we measuring snow: the NOAA/FAA/NCAR winter precipitation test bed. Bull Am Meteorol Soc 93:811-829. https://doi.org/10.1175/ BAMS-D-11-00052.1

Rodriguez-Puebla C, Encinas AH, Nieto S, Garmendia J (1998) Spatial and temporal patterns of annual precipitation variability over the Iberian Peninsula. Int J Climatol 18:299-316. https://doi.org/10. 1002/(SICI)1097-0088(19980315)18:3\%3c299::AID-JOC247\% 3e3.0.CO;2-L

Ruiz-Villanueva V, Díez-Herrero A, Bodoque JM, Ballesteros Cánovas JA, Stoffel M (2013) Characterisation of flash floods in small ungauged mountain basins of Central Spain using an integrated approach. CATENA 110:32-43. https://doi.org/10.1016/J.CATENA.2013.06.015
Sarmadi F, Huang Y, Thompson G, Siems ST, Manton MJ (2019) Simulations of orographic precipitation in the Snowy Mountains of Southeastern Australia. Atmos Res 219:183-199. https://doi. org/10.1016/j.atmosres.2019.01.002

Schaefer JT (1986) Severe Thunderstorm forecasting: a historical perspective. Weather Forecast 1:164-189. https://doi.org/10.1175/ 1520-0434(1986)001\%3c0164:stfahp\%3e2.0.co;2

Seity Y, Malardel S, Hello G, Bénard P, Bouttier F, Lac C, Masson V (2011) The AROME-France convective-scale operational model. Mon Weather Rev 139:976-991. https://doi.org/10.1175/2010M WR3425.1

Serrano-Notivoli R, Beguería S, Saz MÁ, Longares LA, de Luis M (2017) SPREAD: a high-resolution daily gridded precipitation dataset for Spain - an extreme events frequency and intensity overview. Earth Syst Sci Data 9:721-738. https://doi.org/10.5194/ essd-9-721-2017

Serrano A, García JA, Mateos VL, Cancillo ML, Garrido J (1999) Monthly modes of variation of precipitation over the Iberian Peninsula. J Clim 12:2894-2919. https://doi.org/10.1175/15200442(1999)012\%3c2894:MMOVOP\%3e2.0.CO;2

Smith CD, Ross A, Kochendorfer J, Earle ME, Wolff M, Buisán S, Roulet Y-A, Laine T (2020) Evaluation of the WMO Solid Precipitation Intercomparison Experiment (SPICE) transfer functions for adjusting the wind bias in solid precipitation measurements. Hydrol Earth Syst Sci 24:4025-4043. https://doi.org/10.5194/ hess-24-4025-2020

Smith RB, Barstad I (2004) A linear theory of orographic precipitation. J Atmos Sci 61:1377-1391. https://doi.org/10.1175/15200469(2004)061\%3c1377:ALTOOP\%3e2.0.CO;2

Stanley, T., Kirschbaum, D.B., Pascale, S., Kapnick, S., 2020. Extreme precipitation in the Himalayan landslide hotspot, in: Advances in Global Change Research. Springer. 1087-1111. https://doi.org/ 10.1007/978-3-030-35798-6_31

Stimberis J, Rubin CM (2011) Glide avalanche response to an extreme rain-on-snow event, Snoqualmie Pass, Washington. USA J Glaciol 57:468-474. https://doi.org/10.3189/002214311796905686

Taylor KE (2001) Summarizing multiple aspects of model performance in a single diagram. J Geophys Res Atmos 106:7183-7192. https://doi.org/10.1029/2000JD900719

Valenzuela P, Iglesias M, Domínguez-Cuesta M, Mora García M (2018) Meteorological patterns linked to landslide triggering in Asturias (NW Spain): a preliminary analysis. Geosciences 8:18. https://doi.org/10.3390/geosciences8010018

Venables WN, Ripley BDMAS, with S., (2002) Modern Applied Statistics with S, 4th edn. Springer, New York

Weingartner R, Barben M, Spreafico M (2003) Floods in mountain areas-an overview based on examples from Switzerland. J Hydrol 282:10-24. https://doi.org/10.1016/S0022-1694(03) 00249-X

Publisher's note Springer Nature remains neutral with regard to jurisdictional claims in published maps and institutional affiliations. 